\title{
The Limits of Radical Parties in Coalition Foreign Policy: Italy, Hijacking, and the Extremity Hypothesis
}

\author{
Fabrizio Coticchia \\ University of Genoa \\ AND \\ Jason W. Davidson \\ University of Mary Washington
}

\begin{abstract}
Scholars increasingly suggest that coalition governments produce more extreme foreign policies than single-party governments. Extremity is especially likely when governments include radical parties that take extreme positions on foreign policy issues and are "critical" to the government's survival, as the radical parties push the centrist ones toward the extremes. A look at Italy's Second Republic provides an important counterpoint to the extremity hypothesis. In three high-profile cases of military operations-Albania 1997, Kosovo 1999, and Afghanistan 200608-Italy had a center-left government that depended on radical parties for its survival. In all cases, the radical parties opposed military operations but did not prevent the government from acting by forcing the government's fall. Our article seeks to explain the limits of leftist radical parties in Italy's Second Republic. We argue first that radical parties are reluctant to threaten or force government collapse as this can lead to an opposition coalition coming to office and voters' being blamed for the outcome. Second, we claim that foreign policy has been less important to radical parties than domestic issues. Finally, we argue that radical parties have appealed to their voters through theatrical politics and have affected the implementation of military operations.
\end{abstract}

Scholars studying the foreign policies of democracies with coalition governments have increasingly argued in favor of an "extremity hypothesis." In 2008, Juliet Kaarbo and Ryan Beasley first made the case that coalition governments are more likely to adopt extreme foreign policies than single-party governments. One reason why coalition governments are more likely to be extreme is that they are vulnerable to being hijacked by junior parties (Kaarbo and Beasley 2008, 70). The literature further suggests that junior party hijacking that leads to extreme policy

Fabrizio Coticchia is Assistant Professor at the University of Genoa. He has been Jean Monnet Fellow at European University Institute (EUI) and research fellow in International Relations at the Scuola Sant' Anna (Pisa). His fields of research are contemporary warfare, strategic culture, public opinion and military operations, Italian and European defense policy. His most recent book is "The Transformation of Italian Armed Forces in Comparative Perspective. Adapt, Improvise, Overcome?” (with F.N. Moro), Ashgate, 2015.

Jason Davidson is a Professor of Political Science and International Affairs at the University of Mary Washington in Fredericksburg, Virginia. His most recent book is America's Allies and War: Kosovo, Afghanistan, and Iraq (Palgrave Macmillan, 2011). His research focuses on alliance politics and decisions to use force. 
is especially likely when a junior party is critical to the government's survival and when the junior party is ideologically more extreme than the larger parties in the coalition. Because critical parties threaten government survival, it makes good sense for larger parties to pay attention to them and be willing to compromise on policy. Also, when junior parties are more ideologically extreme than their coalition partners, the result of hijacking is more likely to be extreme policy than would be the case if the larger party were more extreme and a junior party member were more moderate.

The record of center-left governments in Italy's Second Republic provides a series of puzzling anomalies to the literature's claims about hijacking and the extremity hypothesis. In all three cases-Albania 1997, Kosovo 1999, and Afghanistan 2006-08 - where the center-left debated the initiation or extension of military operations, radical parties did not influence the fundamental policy decision to initiate or extend military operations. This pattern is especially striking because in all three cases the coalitions contained junior parties-the Communist Refoundation, the Greens, and/or the Party of Italian Communists-that were critical to the government's survival, were more extreme than the larger parties, and took an extreme policy position (against military operations). Yet, in all three cases, the government adopted a moderate policy position. How can we explain these puzzling anomalies to the extremity hypothesis? In this paper, we explore three mutually compatible hypotheses to explain why radical parties did not affect the fundamental policy decision despite a reasonable expectation grounded in the literature that they would have done so. First, radical parties may be reluctant to threaten or force government collapse out of fear that voters will blame them for bringing the center right into power. Second, foreign policy has had less salience to Italy's radical parties than it has to its other parties and has been less important to the radical parties than domestic issues. Third, radical parties have addressed their voters' concerns through theatrical politics (e.g., participating in protests) and through influencing the way Italian military operations are carried out.

This paper offers three main contributions. First, Italy is an increasingly important player in instances of the use of force. As of the first half of 2014, Italy had over 5,000 troops deployed in thirty-three missions around the globe. ${ }^{1}$ Since 2000 , the overall troop strength has varied from 6,500 to 10,000 , with an average of 8,000 troops employed abroad (Ignazi, Giacomello, and Coticchia 2012). As stated by Brighi $(2013,6)$, Italy is "a necessary and inescapable country in contemporary international affairs." After the end of the bipolar era, Italy has provided a relevant contribution to the United Nations, European Union, and North Atlantic Treaty Organization (NATO) operations, portraying itself as a global "peacekeeper" (Giacomello and Verbeek 2011). Understanding why radical parties have not limited Italy's military operations abroad is consequently of great policy importance. ${ }^{2}$ Second, this paper has much to offer to the literature on coalition governments and foreign policy. Anomalous cases can reveal underlying and important causal variables that existing studies have missed and/or limitations in quantitative studies and the databases they rely upon. Finally, this paper can contribute to the Italian debate on electoral reform. Many argue that Italy must avoid the destabilizing effects of small radical parties by enacting electoral rules that will limit the success of such parties. ${ }^{3}$ Our paper demonstrates that

\footnotetext{
${ }^{1}$ http://www.difesa.it/OperazioniMilitari/Documents/SIT\%20ANNO $\% 202014 \% 20$ al\% 2025\%20febbraio\% 202014. pdf.

${ }^{2}$ For a recent study of the influence of the right-populist Northern League on the center-right's foreign policy, see Verbeek and Zaslove (2014).

${ }^{3}$ The Italian Prime Minister, Matteo Renzi, has presented his current electoral reform project mainly aiming at "reducing the hijacking power of the junior parties." Quoted in Il Corriere della Sera, January 14, 2014, available at: http://www.corriere.it/politica/14_gennaio_18/renzi-prima-berlusconi-vede-scelta-civica-socialisti9abf4c80-8023-11e3-be9a-e1e430257234.shtml.
} 
while small radical parties may disagree vehemently with the center left on military operations and may have the ability to bring down governments, they do not do so over these issues, suggesting that small radical parties are not as destabilizing as one might think.

\section{Critical Radical Parties and Moderate Policies}

In this paper, we seek to explain the conditions under which critical radical parties are not influential even though one might expect them to be. Juliet Kaarbo $(1996,507)$ defines critical parties as “... a small party in a minority or minimum winning coalition that has the power to dissolve the government by defecting from the coalition and taking away the number of parliamentary seats it controls that are necessary for the maintenance of the cabinet." We are interested in critical radical parties; that is, they are significantly further along the left/right continuum than the larger parties in the coalition. We define as "radical critical parties" those that adopt transformative aims and locate themselves to the left of the PES (Party of European Socialist), including: Rifondazione Comunista, Comunisti Italiani, and Verdi. ${ }^{4}$

One might question whether the policies adopted in these three cases were actually moderate given that they entailed the use of force. Kaarbo and Beasley $(2008,73)$ define extremity as very high levels of cooperation or conflict. The outcome of all three cases here represents a mixture: conflict as they entail the use of force and cooperation because all three operations occurred through multilateral organizations. In Albania in 1997, Italy led a UN-authorized stabilization force made up of EU members. In Kosovo, Italy joined its NATO partners in air operations to end Serb violence against Kosovar Albanians. In Afghanistan, Italy again joined NATO members under a UN mandate to stabilize Afghanistan. In these three cases, the radical parties preferred an extreme pacifist policy opposed to any military intervention, referred to as "senza se, senza ma" (no ifs, no buts) pacifism. In all three of these cases, had the radical parties won and had Italy refused to participate, such inaction would have been seen as extraordinary (Davidson 2011, 99; Ignazi, Giacomello, and Coticchia 2012).

\section{The Coalition Politics and Foreign Policy Literature}

In the past two decades, the literature on coalition politics and foreign policy has grown significantly, and much of it supports the aforementioned extremity hypothesis. In a 1996 article, Kaarbo sought to explain junior coalition partners' influence. Her case study analysis concluded that the central factors were: junior and senior party unity, junior party "strategies of influence" (whether they threatened to force government collapse), and whether the locus of decision making was beneficial to the junior party. Kaarbo (2008) subsequently suggested that the social psychological dynamics of small groups might also allow junior parties to influence government policy.

Binnur Ozkececi-Taner (2005) examined Turkish foreign policy and concluded that the ideational position of actors in coalition governments was likely to affect foreign policy choice when the issue was highly salient for the actor, when the actor controlled a relevant ministerial position, and when the party was relatively consistent on the issue.

As mentioned previously, Juliet Kaarbo and Ryan Beasley's 2008 Foreign Policy Analysis article is the most significant work on the extremity hypothesis. Prior to their article, the literature was divided between those who argued that coalitions

${ }^{4}$ For a literature review of Italian leftist "radical" parties, see Calossi and Sozzi (2012). 
were more aggressive and those who argued that coalitions were more peaceful than single-party governments. Kaarbo and Beasley's quantitative analysis shows that coalition governments produce more extreme behavior (in terms of levels of conflict or cooperation) than single-party governments. Kaarbo's (2012) book also included case study analysis to examine how coalition governments result in extreme policy. Kaarbo $(2012,236-37)$ argues that the following factors best explain the outcomes: party disunity, issue divisibility, locus of authority, and political calculation.

Joe Clare's article (2010) is one of the few works to look at ideologically extreme parties. Clare points out that not all critical parties are willing to force government collapse. Extreme parties are willing to threaten collapse because if they concede, their voters will punish them. Moreover, the senior parties take radical junior parties threats seriously, knowing that these parties will suffer if they compromise. Clare's quantitative analysis demonstrates that outlier parties drive policy toward extremes, providing confirmation of one mechanism of the Kaarbo and Beasley extremity hypothesis.

Opperman and Brummer (2013) elucidated two different pathways junior coalition parties have to influence policy. Junior parties may control a foreign policy relevant ministry and may use it to influence policy. Absent ministerial control, junior parties can influence policy through coalition agreements or committee oversight. Opperman and Brummer $(2013,4)$ have a broad definition of influence which "is not restricted to the substance of foreign policy decisions, but extends to the process and agenda of decision-making, including non-decisions and the deferral of decisions." Sibel Oktay's recent (2014) article presents quantitative analysis to demonstrate the importance of ideological diversity and coalition strength in explaining varying levels of commitment. She argues, for example, that minimum winning coalitions with high ideological diversity engage in more intense commitments. Radical party hijacking is one explanation for this outcome. Finally, Beasley and Kaarbo's (2014) article uses quantitative analysis to explain why coalition governments engage in extreme behavior. They conclude that hijacking cannot explain the outcomes, but government strength can explain extremity and the number of parties in the coalition can help explain conflictual behavior.

The coalition foreign policy literature suggests that there is a growing support for the extremity hypothesis. This paper seeks to offer three outlier cases that suggest important underlying factors that may stand between critical junior parties and extreme policy outcomes. The coalition foreign policy literature also demonstrates a few weaknesses. The literature has not sufficiently studied cases of extreme or radical parties and the conditions under which they are more/less likely to hijack policy. Joe Clare's (2010) article is an important exception and a fruitful contribution. We hope to further the study of coalition governments and foreign policy through an exploration of the conditions that limit critical radical parties from influencing foreign policy.

\section{The Theoretical Argument}

\section{The Blame Hypothesis}

By definition, critical radical parties are able to threaten and/or force government collapse and they may often desire to do so, especially as they are more likely to achieve their policy objectives when they make threats (Kaarbo 1996, 523). Critical radical parties may suffer negative consequences when they threaten to bring down the government, however. We assume radical parties will not threaten government collapse unless they are willing to follow through because actors who make threats and do not follow through lose credibility. 
What are the costs of forcing a government to collapse ${ }^{5}$ It is reasonable to assume that median voters will, ceteris paribus, favor stability and competent governance over coalitions that are internally divided and collapse before they have completed their mandate. ${ }^{6}$ Given voters' preferences for stability and governance, in a bipolar political system (one with alternating left/right governments) it is likely to expect a center-left government collapse to result in a subsequent election victory for the center right. In a bipolar system, we expect median voters to react to center-left collapse by moving their vote to the center right. We can also expect even dedicated left-leaning voters to punish parties that force government collapse by moving their vote to another party on the left (not complicit in the collapse). In the event that the center right wins an election in the wake of a centerleft collapse, we can expect center-left voters and perhaps even some radical left voters to blame the party or parties that forced the government to fall. That blame will translate into a worsening of the radical party's position within the center left. A final possibility is that the center-left may react to radical parties' threat/action to force collapse by forming an alternate coalition with centrist parties. This is yet another reason for radical parties to be reluctant to threaten collapse.

Of course, we are not arguing that critical radical parties will never threaten/force government collapse. We know from experience that it happens, and if radical parties never threatened collapse, they would not maximize their leverage. Rather, we argue that critical radical parties will be extremely reluctant to threaten collapse because of the negative consequences of doing so, using this lever only in extreme circumstances. We expect critical radical parties to threaten collapse when they clash with their centrist counterparts over policy issues of the utmost importance to the radical parties (more on the salience hypothesis follows). Finally, we argue that if radical parties force government collapse, they will incur voter blame for a reasonable amount of time (at least a full electoral cycle) and, as such, will be even more reluctant than normal to threaten collapse to achieve their policy goals.

\section{Relative Salience}

Political parties, like the societies they emerge from, care about some issues more than others. Radical parties in some advanced democracies are especially concerned with economic and environmental issues and less concerned with foreign policy and military operations. Some existing scholarship suggests that the relative salience of the issue at hand will have an impact on a party's influence on policy outcomes (Ozkececi-Taner 2005), whereas other work casts doubt on the importance of salience (Kaarbo 1996). Even extreme or radical parties cannot have equally intense preferences about all issue areas. Given that, as mentioned previously, forcing government collapse generates negative consequences, we expect relative salience to be tied to threats to collapse. When military operations are a low salience issue relative to other issues for the critical radical party, we expect the party to refrain from threatening collapse even when it is opposed to the coalition's policy. It is also important to consider whether the military operations issue is relatively more salient for the larger centrist party or the radical party. If the issue is very important for the larger party, the radical party will understand that the larger party is unlikely to compromise and, thus, the government will collapse and the radical party will suffer the aforementioned blame fallout (and still not achieve its objective). The radical party might be willing to pay this price for issues of the utmost importance, but is unlikely to do so for issues of lower salience. ${ }^{7}$

\footnotetext{
${ }^{5}$ In the event that the senior party concedes to the junior party, this logic does not unfold.

${ }^{6}$ On median voters and stability in bipolar systems, see, among others, Duhamel (1997).

${ }^{7}$ Indeed, the Italian radical parties we study refused to compromise specifically on domestic issues (the economy, the welfare state, political reform), as occurred in 1998 when the Prodi's government fell on the budgetary plan.
} 
But how do we know whether radical or centrist parties see military operations as a high salience issue? Party platforms may provide an indication, especially in terms of the placement of foreign policy relative to domestic and the percentage of space given to each. That said, while space in a program is not free, it is relatively cheap. One important indicator of issue salience is cabinet portfolio demands and allocation. Portfolio allocation is driven by relative power and by relative interest in the issue (Opperman and Brummer 2013, 5). Parties that see foreign policy as important relative to domestic issues will ask for and attain cabinet seats to reflect it. If the party's power does not allow it to attain a prestigious seat such as Foreign Minister or Defense Minister, we would at least expect a small party with high foreign policy salience to attain an undersecretary position in a relevant ministry.

Finally, relative salience may serve as a driver of other factors that may lead radical parties to refrain from threatening/forcing government collapse. First, because radical parties have a relatively low salience for foreign and military policy, they are less likely to develop a strategic counter-narrative to critique the larger centrist party in their coalition. As such, in debates on military operations, their critique of the government's proposed policy will be shrill and unlikely to win over the public or other parties. Second, radical parties' low salience for foreign policy will influence the calculus of the party elites. Top figures in radical parties will translate their party's critical status into cabinet positions. Such figures will be unlikely to risk their cabinet positions (which they would lose in the event of a government collapse) for an issue of low salience to them. Finally, when military operations are of low salience for critical radical parties, they should be receptive to senior parties' attempts to frame the operations in a way that makes them acceptable (e.g., as a "peace mission"). ${ }^{8}$

\section{Theatrical Politics and Implementation}

To say that military operations are less important to most radical parties than domestic issues is not to say that they are unimportant. Radical party voters are often outspoken opponents of military operations. As such, radical parties stand to gain from providing attention to foreign and military policy even if they do not take the more costly step of threatening/forcing government withdrawal in an attempt to force their government to not engage in/renew military operations. ${ }^{9}$

First, parliamentarians from radical parties may engage in theatrical or symbolic politics. When radical parties cannot deliver in policy terms, they-as other kinds of groups-may appeal to their constituents by playing a high-profile role in emotive rallies and protests (Kaufman 2006, 52). Radical party figures may also make public statements opposed to military operations. By engaging in theatrical politics that contradict their governmental/parliamentary behavior, critical radical parties are glaringly inconsistent, making them even less likely to influence major policy decisions (Ozkececi-Taner 2005, 270).

Second, radical parties may accept that they cannot influence their government's decision to engage in or extend military operations, but focus instead on influencing the implementation of military operations. As Opperman and Brummer note, junior parties that may not be able to influence core policy decisions can pose "... a restraint on the senior party's ability to implement its foreign policy agenda to the full" (Opperman and Brummer 2013, 6). Given radical parties' preference for peace (Ignazi, Giacomello, and Coticchia 2012), we can expect them to seek to attain very restrictive rules of engagement and to attain a

\footnotetext{
${ }^{8}$ On issue framing as a way to avoid clashes among parties, see Kaarbo $(2008,68)$.

${ }^{9}$ We group theatrical politics and implementation together because they are two ways radical parties can address their voters' concerns despite remaining in the governing while the military operations proceed.
} 
focus on training and reconstruction activities and away from kinetic operations. Radical parties may even work to limit the deployment of materiel necessary for engaging in robust action on the battlefield.

\section{Case Selection and Alternative Pathways}

In order to assess the above-mentioned hypotheses, the paper analyses the cases of Albania, Kosovo, and Afghanistan. We have chosen the only three cases in postCold War Italy where critical radical leftist parties favored an outcome different from the government's proposed path as a test of the limits of radical parties. ${ }^{10}$ Given this, we are studying what is currently an empirical universal and variation on the dependent variable is not possible (George and Bennett 2005, 77). Although there was variation in the nature of the operations (stabilization and air strikes), it was not relevant to our analysis. ${ }^{11}$ Our primary interest is in the decision to send or keep Italian forces abroad, including parliamentary debates on financing the missions. We also explore subsequent decisions on the rules governing those forces. The main sources are parliamentary debates (both in assembly and in committee), parties' electoral platforms, official documents, newspapers articles, and interviews.

The coalition foreign policy literature suggests two pathways other than hijacking that one might imagine could explain the outcome here. First, the literature argues that coalitions adopt extreme policies to divert attention from internal weakness and, thus, inability to address domestic policy challenges (Kisangani and Pickering 2011). The diversionary pathway cannot explain the outcomes. The first Prodi government was responsible for the major domestic policy feat of attaining Italian entry into the EU's common currency and 1997, 1999, and 2006 were all years of moderate growth of the Italian economy. ${ }^{12}$ Moreover, the diversionary pathway suggests that weaker coalitions should generate extreme policies. In all three cases, the governments had a very thin margin of support, yet adopted moderate policies, so this pathway is unable to explain the cases. Finally, the controversies over foreign policy often represented the "first crises"13 within the majority coalition before other problems erupted (on welfare, job creations, etc.), as occurred in the case of "Alba" in 1997, so it is impossible for the foreign policy decisions to have been taken to divert from the domestic policy crises (Blim 2000). Second, the literature proposes that coalitions may adopt extreme policies when a high number of governing parties leads to a lack of accountability (Beasley and Kaarbo 2014). This pathway is also not capable of explaining the three cases. One problem with this pathway is that the coalitions in the first two cases consisted of roughly half as many parties (seven) as the coalition for our third case (fourteen). ${ }^{14}$ In addition, the "personalization of politics" (Conti 2008, 460) and "greater prime ministerial authority" (Bull and Pasquino 2007, 678) contributed to increase accountability in the bipolar Italian "Second Republic."15 Moreover, as outlined in

\footnotetext{
${ }^{10}$ For this reason, we have excluded the cases of Iraq and Lebanon because all parties in center-left coalition agreed.

${ }^{11}$ One might argue that because the Afghan mission was already deployed, it was different from the other cases in that a "support our troops" and/or "rally around the flag" effect explains the decision to remain. The central problem with this argument is that the radical parties continued to express their opposition to the mission while Italian troops were deployed. In fact, as we document in the case, rather than mute their concerns, radical left leaders publicly called for Italy to withdraw from Afghanistan even in the wake of attacks on Italian troops.

${ }^{12}$ http://www.imf.org.

${ }^{13} \mathrm{http}: / /$ www.repubblica.it/online/fatti/rifondazione/prodi/prodi.html.

${ }^{14}$ The figures refer to the Chamber of Deputies. For 2006, see De Sio (2007). For the 1996 elections, see D’Alimonte and Bartolini $(1997,128)$.

${ }^{15}$ On the breakdown of the Italian party system and the "Seconda Repubblica," see Cotta and Isernia (1996) and Ieraci (1996). On the "bipolar tendency" of the fragmented and unstable Second Republic, see D'Alimonte and Bartolini (1997).
} 
detail below, the major center-left party took accountability for each of the three major decisions under study.

\begin{abstract}
Albania 1997
The main goal of operation "Alba" (April-August 1997) was to help the Albanian government to restore law, holding free and fair elections. Albania was on the brink of civil war because of the growing social, economic, and financial instability after the collapse of investment companies and the resulting protests and violence. For the first time, Italy guided an all-European multinational military force, assuming a leading role within different multilateral frameworks (United Nations, Orgainzation for Security and Co-operation in Europe (OSCE), and European Union). Italy contributed 2,800 troops to the Multinational Force of Protection, which consisted of 7,000 European soldiers. The mission mainly focused on protecting food deposits, escorting convoys, and patrolling roads.

In the Second Republic, Italy moved from constrained coalitions to alternating governments (Cotta and Verzichelli 2000). The center-left won the elections in April 1996. The coalition cabinet was composed of Partito Democratico della Sinistra-PDS (Democratic Party of the Left) Partito Popolare Italiano-PPI (Italian Popular Party), Rinnovamento Italiano-RI (Italian Renewal), Verdi (Greens), and other very small parties. For the purpose of the paper, we consider both Rifondazione and Greens as "critical radical parties." Rifondazione Comunista (RC) obtained a remarkable 8.57 percent and twenty "crucial" seats in the Chamber of Deputies, ${ }^{16}$ whereas the Greens reached the 2.5 percent and fourteen seats. RC was not formally part of the government coalition, instead providing "external support" to the cabinet (without ministers). ${ }^{17}$

The parliamentary bill ${ }^{18}$ authorizing the mission to Albania (April 1997) passed without the support of Communist Refoundation, whereas the Greens approved. Despite Rifondazione's opposition, Prodi's government did not collapse. The RC provided its vote of confidence to the cabinet on 11 April, two days after having voted against the mission. Moreover, RC voted in favor of extending the mandate in July, but forced the adoption of a deadline for the end of the operation. Rifondazione opposed expanding the mission's tasks (as advocated by the center-right), voting for the financing of its last weeks. ${ }^{19}$ In addition, the Secretary of Rifondazione, Fausto Bertinotti, persistently stressed the political will to support Prodi, avoiding threatening the survival of the cabinet. Bertinotti clearly stated the RC position: "No to the mission, no to the crisis of the government." 20

Nevertheless, Prodi was able to authorize the intervention only thanks to the center-right opposition. This was an historical event for Italy: The government required opposition support to authorize an important foreign policy decision. However, the internal divisions highlighted the fragility of the cabinet, which in fact fell one year later over a domestic policy dispute. Thus, why did Rifondazione take a clear position against the military mission but not prevent the government from continuing the operation by forcing its fall (as would happen on domestic policy issues in 1998)?
\end{abstract}

\footnotetext{
${ }^{16}$ The Centre-Left coalition led by Romano Prodi took 327 seats out of 630 .

${ }^{17}$ Given the RC's ability to threaten government survival, however, the case is still a fair test of the hijacking logic of the extremity hypothesis.

${ }^{18}$ Decree-law (converted to Law on 24 April, 1997, No. 108) No. 2387, XXII Legislature.

${ }^{19}$ Nardini, Maria Celeste (RC). Defense Commission, Chamber of Deputies, June 5, 1997.

${ }^{20}$ Bertinotti, Fausto. Chamber of Deputies, April 11, 1997.
} 


\section{Blame Hypothesis}

The Prodi government was the first center-left cabinet of the Seconda Repubblica, and consequently, there were not previous cases of radical left parties that had fostered the breakdown of the ruling coalition. Nevertheless, the 1994 fall of the first Berlusconi government was caused by the withdrawal of a junior party, the Lega Nord (Northern League). Looking at the public and parliamentary debates related to the Albanian crisis, it emerges that Communist Refoundation was deeply concerned about the charge of "being the Lega Nord of the center-left," whereas senior parties denounced the irresponsibility of the RC. ${ }^{21}$

As stated by the President of Rifondazione, Armando Cossutta, the collapse of the government would have represented a loss for the RC. ${ }^{22}$ In addition, he explicitly recognized that in the case of the breakdown of the government, the center-right would have surely won in the coming election, whereas the RC would have lost several seats in the Parliament. ${ }^{23}$ In order to avoid such a likelihood, he even considered taking part in the government. ${ }^{24}$ As well explained by Giulio Zincone: "Bertinotti can't afford a crisis because RC would be annihilated, it would be portrayed as a residual Stalinist party. [Bertinotti] would be criminalized by the media as a traitor, as a flanker." ${ }^{25}$ On the whole, Rifondazione made a comprehensive communication effort, spreading a clear message: The dissent was limited to the Albanian operation, whereas the RC wanted to avoid government collapse. Also the Greens, who voted in favor of the operation, strongly affirmed the need to preserve the existing structure of the majority coalition, avoiding alternative (and more centrist) alliances. ${ }^{26}$ According to Bertinotti, "Alba" should not have been transformed into "a problem of stability for the majority coalition." ${ }^{27}$ Indeed, Prodi visited the President of the Republic after RC's previously discussed no vote on Alba (as required by the opposition as a crucial condition in order to achieve a bipartisan vote), but then he obtained the whole support of the coalition (RC included). Later the opposition defined Bertinotti as "funny but harmless."28

On the whole, the concern of being the Lega Nord of the coalition played a role in the case of Alba, and RC never threatened the survival of the government.

\section{Relative Salience}

In this case, the critical radical parties refrained from threatening collapse, despite their opposition to "Alba," because the military mission was a low salience issue in comparison to other domestic themes. Evidence of relative salience is derived from different sources: parties' platforms, portfolio allocations, newspaper articles, and parliamentary debates. The 1996 electoral program of Rifondazione ${ }^{29}$ devoted its last "chapter" (one out of ten) to foreign and defense policy. The overall space assigned to defense issues was minimal. The main elements were the opposition to all military interventions abroad (apart from those under UN command) and to the "anachronistic military alliances" (i.e., NATO), the promotion of a defense model based on conscription and the cut of military expenditures. In general, few sentences were dedicated to Italian defense in comparison to the rest of the platform.

\footnotetext{
${ }^{21}$ “D'Alema: Bertinotti? Ł̀ inaffidabile.” August 4, 1997. La Stampa.

22"Rifondazione: un no alla missione ma senza crisi." April 4, 1997. Il Corriere della Sera.

23"Vogliono scaricarci." April 7, 1997. La Stampa.

24“Cossutta: siamo pronti a entrare nel governo." April 10, 1997. La Stampa.

${ }^{25}$ Zincone, Giulio. April 5, 1997. "Il cinico Bertinotti". Il Corriere della Sera.

${ }^{26}$ Cento, Paolo (Verdi). Chamber of Deputies, April 11, 1997.

27"Bertinotti: ma la maggioranza non franerà per Tirana." April 3, 1997. Il Corriere della Sera.

${ }^{28}$ Casini, Pier Ferdinando (CCD-CDU—Catholic Democratic Centre/United Democratic Christian). Chamber of Deputies, April 11, 1997.

${ }^{29}$ See Rifondazione Comunista,1996. Ricominciare da sinistra per l'alternativa.
} 
The Greens were part of the broader center-left coalition "L'Ulivo," whose platform put foreign and defense policy issues almost at the beginning of the program, distinguishing among specific topics such as the reform of the United Nations, the Maastricht treaty, or development cooperation. ${ }^{30}$ Moreover, two paragraphs focus specifically on regional crises and the new defense model, advocating for a more active Italian role through multilateral operations. The platform does not reflect the Green's radical pacifism. As already stated, portfolio allocation could be an indicator of salience. The RC guaranteed only an external support of the cabinet, without ministers. On the contrary, the Greens had one minister and three undersecretaries, but none in foreign policy or defense offices.

In Parliament, Rifondazione limited its dissent to the military mission while focusing mainly on domestic issues. As explained by Bertinotti: "We will remain in the majority coalition until the cabinet cuts healthcare and pension funds." ${ }^{31}$ RC confirmed the opposition to "Alba" but without calling into question the survival of the government. ${ }^{32}$ The cabinet would have collapsed only in the case of deep divergences on issues such as the "welfare state." ${ }^{33}$ Although the leader of the PDS, Massimo D'Alema, openly accused RC of considering "Alba" a minor issue, ${ }^{34}$ Rifondazione charged those who invoked the crisis on Albania of "using the crisis to exclude RC from the majority coalition," thus allowing the cabinet to modify its policy on the welfare state, which evidently represented the crucial issue at stake. ${ }^{35}$

D'Alema stressed "a political and cultural dissent within the Italian left concerning foreign policy." "However, looking at the political debate, Rifondazione failed to develop an effective counter-narrative. RC justified its opposition because of the "military nature" of the operation, which was illustrated by the "strong military naval patrol." 37 The RC described antimilitarism as an undeniable core value and called for broader involvement of the United Nations and European Union, the postponement of the mission (not its cancellation), and the effective engagement of civilian NGOs. ${ }^{38}$ Nevertheless, the strategic narrative adopted by the cabinet, which was based on shared values such as multilateralism, peace, and humanitarianism, was apparently consistent with the core elements of RC's narrative. For example, Minister Livia Turco described "Alba" as a pure humanitarian mission composed of "volunteers, associations, soldiers, and nuns." ${ }^{39}$ The deputy director of Il Manifesto highlighted the "loneliness of the pacifists." ${ }^{40}$ In addition, seventyseven percent of Italians were in favor of the naval patrolling, and more than half of the sample approved "Alba." More importantly, even the majority of the RC voters supported the mission. ${ }^{41}$ The Greens embraced the strategic narrative crafted by the cabinet, labeling "Alba" as a: "civil mission with a humanitarian nature." As stated by the leader of the Greens, Luigi Manconi, the humanitarian nature of the intervention allowed them to de-emphasize their dissent over other issues (e.g., the naval patrol). ${ }^{43}$ In summary, the relative salience clearly emerges from

\footnotetext{
${ }^{30}$ The program is available at: http:/ / www.perlulivo.it/radici/fatti/introduzione.html.

31 "Direzione Comunista per smentire i dissensi." April 6, 1997. Il Corriere della Sera.

${ }^{32}$ Bertinotti, Fausto. Chamber of Deputies, April 11, 1997.

33"Bertinotti: ma la maggioranza non frenerà per Tirana.007),,,d Democratic Christian).” April 3, 1997. $I l$ Corriere della Sera.

${ }^{34}$ D'Alema, Massimo. Chamber of Deputies, April 11, 1997.

${ }^{35}$ Diliberto, Oliviero (RC). Chamber of Deputies 9 April.

${ }^{36}$ D'Alema, Massimo. Chamber of Deputies, April 11, 1997.

${ }^{37}$ Mantovani, Ramon (RC). Chamber of Deputies, April 9, 1997.

38"Rifondazione: vince la linea dura." April 8, 1997. La Stampa.

39"Con i soldati, suore e volontari." April 6, 1997. La Stampa.

40"Compagni, e la tolleranza?" March 30, 1997. La Stampa.

41"Prodi al minimo storico." April 7, 1997. La Stampa.

${ }^{42}$ Paissan, Mauro (Verdi). Chamber of Deputies, April 9, 1997.

43 "Albania maggioranza trasversale." April 3, 1997. Il Corriere della Sera. See also: Leccese, Vito (Verdi). Chamber of Deputies, April 11, 1997.
} 
the parliamentary debates on the extension of the mission (June-July 1997) because of the shared view on the positive results achieved by the "peace and humanitarian" mission and, above all, the lack of an existing counter-narrative. ${ }^{44}$

\section{Theatrical Politics/Implementation}

We argue that radical parties have appealed to their constituents through theatrical politics (e.g., demonstrations, speeches, op-eds, etc.) and have affected the implementation of "Alba." Two main elements can be highlighted. First, both RC and the Greens engaged in several theatrical acts. Rifondazione called for "a national rally against the mission," ${ }^{5}$ whereas the Minister of Environment, the Green Edo Ronchi, participated in controversial antimilitarist rally where the talian armed forces were strongly criticized. ${ }^{46}$ Rifondazione officially proposed the creation of two parliamentary commissions of inquiry regarding the death of migrants in the Adriatic Sea and Italy's hidden economic role in the collapsed Albanian economy. ${ }^{47}$ In addition, both $\mathrm{RC}$ and the Greens called for the resignation of the Ministry of Defense, Nino Andreatta, after the collision between the ships "Kates y Rades" and "Sibilla" (March 28, 1997) that occurred during naval patrol activities carried out by Italian units. ${ }^{48}$ According to the opposition: "RC. conditioned the Italian diplomatic policy towards Albania." ${ }^{49}$

Second, the critical radical parties (especially the Greens) played a role in influencing the implementation of the mission. Rifondazione abstained in the Defense Commission vote and then voted in favor of the operation's extension (which required additional troops), after UN Resolution 1114 (June 1997) prolonged the mission for another 45 days. ${ }^{50} \mathrm{RC}$ justified its vote emphasizing the need to support the government in order to avoid the adoption of new tasks and different rules of engagement to confront local armed groups. ${ }^{51}$ Critical radical parties also attained the enhancement of the humanitarian component of the mission (aid, reconstruction, etc). For example, the Greens portrayed the coordination mechanism among NGOs as a direct consequence of their political action. As stated by the MP Mauro Paissan: "We support the mission because we are satisfied with the conditions we posed, starting from the active involvement of NGOs and civilian associations." 52

\section{Kosovo 1999}

The collapse of the Prodi government (October 1998) paved the way for the creation of the D'Alema cabinet, which was supported by a new coalition. Three new parties (SDI-Italian Democratic Socialist, PdCI-Party of the Italian Communists, and UDR-Democratic Union for the Republic) took part in the center-left alliance that had lost the external support of Rifondazione. In fact, the PdCI (Comunisti Italiani) was created by previous members of the Communist Refoundation who opposed the RC leadership's decision to bring down the Prodi government. The PdCI, led by Armando Cossutta, had twenty-one seats in the

\footnotetext{
${ }^{44}$ See especially the debates in the Chamber of Deputies, July 30, 1997.

45 "Ma Bertinotti: il nostro no è definitivo." April 6, 1997. Il Corriere della Sera.

46“"Ronchi sfila con Rifondazione." April 7, 1997. La Stampa.

${ }^{47}$ Mantovani, Ramon (RC). Chamber of Deputies, June 5, 1997.

${ }^{48}$ Eighty immigrants died. "Verdi e Comunisti: la colpa è di Andreatta." April 1, 1997. Il Corriere della Sera.

${ }^{49}$ Giovanardi, Carlo. (CCD) Chamber of Deputies, June 5, 1997.

${ }^{50}$ See Law 108 that converted the decree-law 2387 and Law 260 (July 1997).

${ }^{51}$ Nardini, Maria Celeste (RC). Defense Commission, Chamber of Deputies, June 5, 1997.

${ }^{52}$ Paissan, Mauro (Verdi). Chamber of Deputies, April 9, 1997.
} 
Chamber of Deputies, whereas the Greens had fifteen seats. Together they were consequently decisive for the survival of the cabinet. ${ }^{53}$

The war in Kosovo represented the hardest test for the PdCI, which portrayed itself as a "reliable party" ${ }^{\text {" }}$ in order to stress the difference with RC. Since the very beginning of the crisis, both the Greens and the PdCI clearly expressed their strong opposition to NATO's operation against Yugoslavia. ${ }^{55}$ The Greens sustained an eventual EU intervention, but they strongly opposed the involvement of NATO ${ }^{56}$ It is worth tracing the different "red lines" that the PdCI drew and then allowed the government to cross. In January, Cossutta highlighted his opposition to the use of Italian bases for an eventual NATO attack. ${ }^{57}$ Then, after Italy provided the bases, he threatened to withdraw his two ministers from the cabinet in the case of an active engagement of Italian armed forces. ${ }^{58}$ After D'Alema sent aircraft against Milosevic, Marco Rizzo (PdCI) defined the invasion of Kosovo by the army as the "insurmountable red line." 59

Despite the humanitarian concern about the crisis ${ }^{60}$ and the "open criticism" 61 toward the intervention, the radical parties always supported the government in the Parliament, approving all the resolutions and bills related to the crisis (whereas, on the contrary, RC firmly opposed government policy). Quite paradoxically, the Italian parliament never voted on the air strikes, whereas the main bill voted by deputies and senators (with a large bipartisan consensus) was related to the humanitarian operation in Albania, aiming to help the flow of refugees from Kosovo. ${ }^{62}$

\section{Blame Hypothesis}

The European elections (June 1999), which occurred just at the end of the bombing campaign over Yugoslavia, represented a severe defeat for the radical parties. The Greens obtained 1.7 percent (in comparison to the 2.5 percent achieved 2 years earlier), the PdCI reached 2 percent and $\mathrm{RC}$ collapsed: from 8.57 percent to 4.2 percent. Looking at the electoral campaign (where RC was constantly accused of the "betrayal" of 1998), it is reasonable to assume that a lot of voters blamed RC for having caused the collapse of Prodi's government. On the contrary, as officially stated by the PdCI, ${ }^{63}$ the pressure from the people to keep the center-left government alive was the main driver of the creation of the party, which was regularly portrayed as a loyal ally.

Thus, the position taken by the PdCI during the war in Kosovo was really complicated. On the one hand, the party expressed its opposition to the military solution: "We reaffirm our strong disapproval of the military intervention, which is illegal." ${ }^{64}$ But on the other hand, the PdCI always supported the cabinet: "We are not looking for crisis, our major goal is to end the war [...]. We perfectly know

\footnotetext{
${ }^{53}$ The majority coalition had 340 seats out of 630 . For a general overview of the Italian role in the war in Kosovo see, among others, D'Alema and Rampini (1999) and Davidson (2011).

54“Fermiamo l'attacco, e' illegittimo." March 26, 1999. La Stampa.

55 “D’Alema: nel Kosovo siamo con la Nato.” January 19, 1999. La Stampa.

${ }^{56}$ D'Alema: nel Kosovo siamo con la Nato."

57"Meglio il Papa di D’Alema.” January 26, 1999. La Stampa. See also "Via libera ai Caschi blu.” February $5,1999$. Il Corriere della Sera.

58“Cossutta da' l'ultimatum al governo." March 28, 1999. Il Corriere della Sera.

59"Gelo nei Comunisti, poi il si’ al premier.” April 15, 1999. Il Corriere della Sera.

${ }^{60}$ On March 24, 1999, NATO launched a massive air attack against Yugoslavia. In June, the collapsing regime accepted the conditions posed by NATO.

${ }^{61}$ See Cossutta, Armando. Chamber of Deputies, March 26.

${ }^{62}$ Decree-law n. 210, April 21, 1999.

${ }^{63}$ See www.comunisti-italiani.it.

${ }^{64}$ Cossutta, Armando. Chamber of Deputies, March 26, 1999.
} 
that there are not alternatives to this government." ${ }^{65}$ According to Cossutta, only by remaining in the government could the party play an "active role for peace." 66 As highlighted also by the leader of the Greens, Luigi Manconi: "A crisis of the government in a so crucial moment, would deliver all relevant decisions in the hands of the military-industrial complex." ${ }^{67}$ In addition, they both feared to be excluded from the majority with the consequence of a "more pro-NATO coalition." 68

Above all, Cossutta clearly emphasized the "sense of responsibility" of the party, distinguishing the PdCI from Rifondazione: "We are not blackmailing the cabinet, as others have done." 69 The most dangerous menace he posed was that of the withdrawal of his ministers from the government. ${ }^{70}$ But Cossutta never threatened the survival of the cabinet. The possible withdrawal of ministers advanced also by the Greens would have represented a significant crisis for D'Alema. The need to avoid blame for being responsible for the collapse of the government, and the necessity to maintain the image of reliable parties (especially for the PdCI) were stronger than the perils of inconsistency between values, rhetoric, and reality.

\section{Relative Salience}

Although the electoral platforms were the same as in the case of "Alba," the brand new PdCI promoted several "workshops" with the aims of elaborating its program. None of the seminars organized in 1999 were devoted to foreign or defense policy, whereas the attention was dedicated to other issues, such as economy or urban security. ${ }^{71}$ In terms of portfolio allocation, although the Greens just added another minister (Equal Opportunities), and continued with the Environment Ministry of Environment and the three undersecretaries (none of them to Foreign Affairs or Defense), the Italian Communists obtained two ministers (Justice and, without portfolio, Regional Affairs) plus three undersecretaries. One of them, Paolo Guerrini, was at the Ministry of Defense. Therefore, the party revealed some interest in foreign policy though not comparable with other issues.

Looking at the public and parliamentary debates, a distinguishing element emerges. Notwithstanding the criticism toward the military intervention, and the opposed views on the legality of the operation, ${ }^{72}$ critical radical parties did not develop a counter strategic narrative on the war. On the contrary, they "desperately" searched for a shared narrative through which to better justify their support for the Italian involvement. For example, Marco Rizzo (PdCI) openly asked for a change in the first relevant resolution proposed by the majority to the parliament in order to find a "common formula" 73 on the crisis.

If the cabinet clearly adopted a very low communication profile on military aspects ${ }^{74}$ the Greens and the PdCI called for a broad conceptual framework that could guarantee a common base among all parties. Multilateralism, peace, and humanitarianism were the core values of the shared narrative. D'Alema affirmed that "the government would have found a peaceful solution to the war."

\footnotetext{
${ }^{65}$ Cossutta, Armando. Chamber of Deputies, March 26, 1999.

66“"Cossutta: Scognamiglio? E' accecato dalla sindrome bellica." May 19, 1999. Il Corriere della Sera.

${ }^{67}$ Manconi, Luigi. Senate, March 26, 1999.

68“"L'ultimatum di Cossutta." April 1, 1999. La Stampa.

69“'Fermiamo l'attacco, e' illegittimo.' March 26, 1999. La Stampa.

70“Cossutta: la maggioranza e' a rischio." March 25, 1999. La Stampa.

${ }^{71}$ See www.comunisti-italiani.it.

${ }^{72}$ The debate was mainly focused on the lack of a UN resolution and the violation of the Article 11 of the Italian Constitution. See, for instance, Luigi Marino (PdCI), Senate of the Republic, March 26, 1999.

73“'Cossutta: la maggioranza e' a rischio." March 25, 1999. La Stampa.

${ }^{74}$ The Italian engagement was defined by D'Alema as "integrated defense activities" (D'Alema and Rampini 1999, 17).

${ }^{75}$ D’Alema, Massimo. Chamber of Deputies, April 13, 1999.
} 
According to the Greens, Italy was the "diplomatic protagonist of peace."76 Thus, they agreed with the "deployment of troops for humanitarian purposes." ${ }^{\text {"In }}$ summary, both junior and senior parties shared the same narratives and conceptual frames. Although the junior parties took "peace" and "war" seriously, ${ }^{78}$ the salience of the issue was much greater for the senior parties and especially for the Democratici di Sinistra (DS). In fact, for the first time, a postcommunist Prime Minister faced a relevant test in the global area, willing to show both personal and national credibility, also through armed forces.

\section{Theatrical Politics/Implementation}

The crisis in Kosovo offers manifold examples of "theatrical politics." The most striking act was the personal visit of Armando Cossutta to Belgrade to meet with Milosevic. Cossutta openly attacked the NATO intervention, minimizing the spread of violence on the ground. ${ }^{79}$ In Italy, despite their role in the government, the radical parties attended several rallies against the war. ${ }^{80}$ In addition, all the undersecretaries of the Greens began to fast in order to "stop the bombs." undersecretary of Defense, Guerrini (PdCI), explicitly criticized NATO's intervention, causing harsh polemics with the minister Scognamiglio. ${ }^{82}$

Regarding the capacity of influencing the operation, the case of Kosovo provides considerable validation. We should distinguish between the two ways critical radical parties have affected Italian Kosovo policy. First, the leftist parties repeatedly called for a diplomatic solution as an alternative to bombing, stopping air strikes, and fostering dialog "against all nationalisms." 83 The Greens and PdCI made proposals such as a "peace conference" or a "brand new international agreement." ${ }^{84}$ These proposals met with success. In fact, the resolutions adopted by a majority of the Italian parliament clearly asked for "the promotion of initiatives aimed at restarting the negotiations" ${ }^{85}$ or even to "stop the air strikes." ${ }^{86}$ At the diplomatic level, D'Alema strongly focused on negotiations and humanitarian dimensions, distinguishing Italy from other allies who often complained about the pressures by Italy (and Germany) toward peace. In addition, Italy presented to the Atlantic Council a specific proposal for negotiations. Of course, despite this Italy continued to engage in air strikes against Serb forces until Belgrade conceded to NATO demands. D'Alema tried to reach a "complex equilibrium between Clinton and the communists." 87 Radical parties deeply appreciated these political efforts as well as the attention devoted to the humanitarian dimension. ${ }^{88}$ After the end of the war, the PdCI emphasized their relevant role in pushing Milosevic toward a peace agreement: "If we were leaving the majority coalition there would be another government that wouldn't have kept the door open to peace." 89

\footnotetext{
${ }^{76}$ Boco, Stefano (Verdi). Senate, March 26, 1999.

${ }^{77}$ Paissan, Mauro. Chamber of Deputies, March 26, 1999

${ }^{78}$ According to MP Mario Brunetti, the issues of war and peace were discriminating factors for the identity of the PdCI. Chamber of Deputies, March 26, 1999.

79"Cossutta vede Milosevic e attacca la Nato.” April 10, 1999. La Stampa.

80"Contro i raid un 'sacco appello'." April 2, 1999. La Stampa.

${ }^{81}$ "Il digiuno dei Verdi a favore di una soluzione politica." April 30, 1999. Il Corriere della Sera.

82“Kosovo, e' polemica alla Difesa Scognamiglio contro il suo vice." May 21, 1999. Il Corriere della Sera.

${ }^{83}$ Boco, Stefano. Senate of the Republic, March 26, 1999.

${ }^{84}$ See, for example, Mauro Paissan (Greens), Chamber of Deputies, April 13, 1999.

85"Mozione Mussi et al." Chamber of Deputies, March 26, 1999.

86“La maggioranza: stop ai raid, tratti l' Onu." May 20, 1999. Il Corriere della Sera.

87"Il difficile equilibrio fra Clinton e i comunisti." April 3, 1999. La Stampa.

${ }^{88}$ Italy set up the operation "Arcobaleno" for distributing aid.

${ }^{89}$ Armando Cossutta, reported in: "D’Alema spera: ora ci siamo." June 4, 1999. Il Corriere della Sera.
} 
Second, the radical parties also affected the implementation of the mission. As revealed by Undersecretary Marco Minniti, the constraints posed on the operations were directly linked to the demands made by the radical parties: ${ }^{90}$ the ground attack missions were reduced and the Italian pilots were not allowed to bomb major Serb cities. In the opening weeks of the war, NATO General Clark complained of the Italian pressures to limit the military scope of the operation. ${ }^{91}$ D'Alema confirmed that the significant constraints were related to the domestic political context. ${ }^{92}$

\section{Afghanistan 2006-2008}

The second Prodi government was formed following the 2006 election. The government had a very narrow edge in the Senate where the Communist Refoundation won twenty-seven seats, whereas the Party of Italian Communists and Greens joined together (with the United Consumers) to win eleven seats. ${ }^{93}$ Their Senate seats made each of these three parties critical to the government's survival.

When the Prodi government took office, 2,000 Italian troops were deployed to Afghanistan as part of NATO's International Security Assistance Force (ISAF) ${ }^{94}$ Although leaders of the critical radical parties had expressed their opposition to the operation, they also made clear that they would not force government collapse over the issue. A small group of "rebel" senators from the radical parties expressed their opposition to the deployment and intention to vote against it despite their parties' attempts to coerce them to vote in favor. In July 2006, the government survived a confidence motion it attached to the renewal of the Italian contingent in Afghanistan. ${ }^{95}$ In February 2007, the Prodi government lost a Senate vote on its foreign policy due to two far-left rebel Senators critical of the Afghanistan mission (Walston 2009). ${ }^{96}$ Soon thereafter, however, Prodi won a confidence motion, and in March 2007, the government won a vote to refinance Italy's military missions abroad, including Afghanistan (this time also with the support of the centrist UDC) .97

The critical radical parties might have been tempted to threaten government collapse. After all, the Italian public was firmly in favor of withdrawing Italian troops from Afghanistan. Moreover, the critical radical parties suffered criticism because of their support for the government on the issue. ${ }^{98}$

\section{Blame Hypothesis}

Italy's radical left had limited experience in government, but the 1998 forced collapse of the first Prodi government hung a shadow over the second Prodi government. As mentioned previously, the RC saw its share of the vote halved between the 1996 election and the 1999 European parliament elections that followed its forced collapse of the first Prodi government. ${ }^{99}$ As the debate over refinancing

\footnotetext{
90 "Minniti: gli aerei erano gia' in volo e non potevamo dirlo." June 11, 1999. Il Corriere della Sera.

91 "Divieto d' attacco per gli aerei italiani" March 29, 1999. Il Corriere della Sera.

${ }^{92}$ D'Alema and Rampini (1999).

${ }^{93}$ http:/ / elezionistorico.interno.it/index.php? tpel $=$ C\&dtel $=09 / 04 / 2006 \&$ tpa $=\mathrm{I} \&$ tpe $=\mathrm{A} \& l$ lev0 $=0 \& l e v s u t 0=0 \&$ es $0=\mathrm{S} \& \mathrm{~ms}=\mathrm{S}$.

${ }^{94}$ http://www.nato.int/isaf/docu/epub/pdf/placemat_archive/isaf_placemat_070129.pdf.

${ }^{95}$ Michilli, Livia. July 29, 2006. "Afghanistan, Via libera finale." Il Corriere della Sera.

${ }^{96}$ Although the far-left rebel Senators opposed the mission, the RC did not vote against it.

${ }^{97}$ Breda, Marzio. March 28, 2007. "Missione, Appello del Quirinale.” Il Corriere della Sera.

${ }^{98}$ Franco, Massimo. January 26, 2007. "L' ala radicale resiste ma non vuole la crisi." Il Corriere della Sera.

${ }^{99}$ http://elezionistorico.interno.it.
} 
the Italian mission loomed in 2006 and 2007, it made sense for the center left to be reluctant to threaten collapse.

Center left, radical left figures, and journalists expressed fears that government collapse would result in a return to power of Berlusconi's center right. D'Alema threatened that the end of the Prodi government could mean the return of the center right and Italian soldiers sent back to Iraq. ${ }^{100}$ As the February 2007 Senate vote loomed, RC leader Franco Giordano warned his party " $[\mathrm{t}]$ he risk is that we will find ourselves three steps back: with Fini at Foreign Affairs, Martino at Defense, and even our soldiers could return to Iraq."101 According to the leader of the Greens, Pecoraro Scanio, the collapse of the government on ISAF would have called into question even the scheduled withdrawal from Iraq. ${ }^{102}$ During the February 2007 Senate debate, Cossutta warned that if the radical left brought down the government " $[\mathrm{w}] \mathrm{e}$ would not be pardoned, we would not pardon ourselves. Because history-we know-does not spare anyone." ${ }^{03}$ In January 2007, the Corriere della Sera noted a concern in the center left that a government fall would lead to a different majority, specifically that "[the RC's] Bertinotti's moderation betrays his concern with avoiding an after Prodi that is seen as a disaster." ${ }^{104}$ Some also appear to have feared that if the radical left threatened government collapse, it would embolden those on the center left-especially with the emergence of the Democratic Party—who preferred a coalition with centrist parties (e.g., the UDC). ${ }^{105}$

\section{Relative Salience}

The portfolio allocation of the Prodi government provides evidence of the priorities of the governing parties. The Democrats of the Left's Massimo D'Alema took the Foreign Ministry and The Daisy Party's Arturo Parisi became the Defense Minister. The radical parties attained cabinet posts, but in areas they were more concerned with: the Greens gained the Environment Ministry, the Italian Communists controlled the Transport Ministry, and the Communist Refoundation won the Social Solidarity Ministry. ${ }^{106}$ The relevant undersecretaries were also held by centrist parties: for example, Foreign Ministry Undersecretary Gianni Vernetti (Margherita) Undersecretary of Defense Giovanni Lorenzo Forcieri (DS).

The 2006 united left electoral program, titled "Per il Bene dell'Italia," featured a brief discussion of foreign policy, covering one and a half sections relative to thirteen sections total, indicating the general low salience of foreign policy. ${ }^{107}$ The left's 2006 party platform suggests that foreign policy was more important for the centrist parties than the radical parties. The content of the foreign policy section of the platform suggests the center-left's priorities triumphed. Instead of the "no ifs, no buts" (senza se, senza ma) extreme pacifism of the radical left, the program specifies the conditions under which force might be used, declaring that "...for today and for the future it should not be possible to deploy Italian Armed Forces beyond national borders without direct and precise mandate from the United Nations and EU."108

\footnotetext{
${ }^{100}$ Caccia, Fabrizio. February 25, 2007. "D'Alema: questa sinistra non serve al Paese.” Il Corriere della Sera.

${ }^{101}$ Meli, Maria Teresa. February 9, 2007. "Giordano e il rischio della mozione: in 10 giorni ci giochiamo il governo." Il Corriere della Sera.

102“Afghanistan, Unione a rischio. Il governo tenta la mediazione.” June 28, 2006. La Repubblica.

103“112a Seduta," 72.

${ }^{104}$ Franco, Massimo. February 3, 2007. "L' altolà del Professore aspettando l' Afghanistan.” Il Corriere della Sera.

${ }^{105}$ Roncone, Fabrizio. February 4, 2007. "Diliberto: il complotto c' è, Romano deve stare attento a Casini e alla Margherita." Il Corriere della Sera.

${ }^{106}$ Italian Politics, 2006.

${ }^{107} \mathrm{http}: / /$ digilander.libero.it/karmaproductions/politica/programma-unione.pdf.

${ }^{108}$ Ibid., p. 109.
} 
Public statements on Afghanistan provide evidence that the radical parties' leadership did not care enough about Afghanistan relative to other issues to risk the government's survival. In April 2006, Oliviero Diliberto (PdCI leader) said regarding Afghanistan: "I remain opposed, but I am not so crazy as to put the coali-

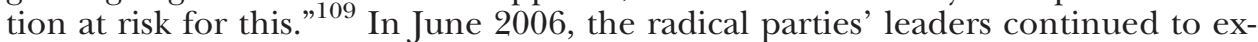
press opposition to the government's decision to remain in Afghanistan, but they also continued to make clear that they would not bring the government down over the issue. ${ }^{110}$ In March 2007, Giordano made clear to his party that he did not want a government crisis over Afghanistan because it was not worth the consequences relative to an issue such as pension reform. ${ }^{111}$

The radical parties' relatively low salience of this issue made them receptive to appealing narrative terms. D'Alema argued that Afghanistan was a UN mission in which NATO “. . .carries out a delicate and necessary military function but the mission is first of all political and civil." ${ }^{112}$ At times, however, the government's attempts at framing did not succeed, such as when D'Alema admitted to RC Secretary Giordano that it is "...difficult to say that aircraft that are called Predator are not aircraft of war." 113

\section{Theatrical Politics/Implementation}

There were two high-profile foreign policy demonstrations during this period and the radical left featured in both. Although neither demonstration was focused on Afghanistan, both included calls for Italy to withdraw its troops. First, leading figures in the radical left participated in the February 2007 demonstrations against the expansion of the US air base in Vicenza. ${ }^{114}$ Second, when George W. Bush visited Rome in June 2007, radical party figures joined the protests against his visit and foreign policy. ${ }^{115}$ In both cases, the Prodi government was able to keep the radical parties' ministers from participating but not other high-profile actors on the radical left. Leading radical left figures reacted to attacks on Italian troops by calling for withdrawal in the press (even while noting that they would not force government collapse on the issue). ${ }^{116}$

Parliamentarians and ministers in the radical left engaged in other theatrical politics as well. The three radical party ministers abstained from the cabinet vote on refinancing the Afghanistan mission in January 2007. ${ }^{117}$ In March 2007, Spanish journalists reported that Italian troops were working to block Taliban fighters fleeing the South and the radical left required Undersecretary of Defense Forcieri to come to the Senate and explain that the troops were not engaging in combat but rather "actions of vigilance." 118 The February 21, 2007, Senate debate allowed almost all of the seven radical left senators who spoke to distance themselves-sometimes quite dramatically-from the Prodi government's foreign policy and its deployment to Afghanistan before all but one announced that they would vote in favor of refinancing. For example, Fosco Giannini (RC) decried

\footnotetext{
${ }^{109}$ Gorodisky, Daria. April 28, 2006. "Diliberto: prima dell' estate tutti a casa Distinguo tra chi attacca civili e militari." Il Corriere della Sera.

${ }^{110}$ Michilli, Livia. June 29, 2006. “Afghanistan, no da otto senatori dell' Unione.” Il Corriere della Sera.

${ }^{111}$ Verderami, Francesco. March 7, 2007. "Parisi, incontro con i pacifisti per 'blindare'il decreto'." Il Corriere della Sera.

112“112a seduta pubblica," Senato della Repubblica, XV Legislatura. February 21, 2007, http://www.senato.it/ser vice/PDF/PDFServer/BGT/253523.pdf, p. 12.

${ }^{113}$ Meli, Maria Teresa. February 10, 2007. "Diliberto: 'Inaccettabile: vuol fare cadere il governo?” Il Corriere della Sera.

${ }^{114}$ Fregonara, Gianna. February 14, 2007. "Diliberto: io sfilerò." Il Corriere della Sera.

${ }^{115}$ Martirano, Dino. May 13, 2007. "E la sinistra radicale prepara il 'No Bush Day'." Il Corriere della Sera.

${ }^{116}$ Garibaldi, Andrea. September 9, 2006. "E sulla missione l' Unione torna a dividersi." Il Corriere della Sera.

${ }^{117}$ Meli, Maria Teresa. January 26, 2007. "Dietro le Quinte." Il Corriere della Sera.

${ }^{118}$ Nese, Marco. March 15, 2007. "L' Italia combatte?" Il Corriere della Sera.
} 
American B-52s bombing Afghanistan, saying "[t]hey are there to control oil routes. They are there to extend NATO's presence and the presence of the US military in the heart of Asia."119

The radical left also appears to have influenced the implementation of the government's Afghanistan policy. The United States asked Italy to contribute more troops and to participate in active combat operations in the south of Afghanistan. The Prodi government refused both requests; given its difficulties in getting approval for its existing mission, it made sense not to agree to an expansion. ${ }^{120}$ Undersecretary Vernetti said the government would not fulfill a June 2006 NATO request for AMX ground attack aircraft to avoid a "fight" in the governing coalition. ${ }^{121}$ The radical left asked for an Afghanistan "exit strategy" and a peace conference; the government refused, with Defense Minister Parisi stating that Italy could not adopt an exit strategy unilaterally. ${ }^{122}$ Finally, it appears likely that the radical parties influenced the government's decision to maintain rules of engagement that limited the Italian contingent's ability to engage in offensive operations. ${ }^{123}$

The Prodi government answered the radical left's call for discontinuity by applying the Military Criminal Code of Peace to troops in Afghanistan. ${ }^{124}$ Moreover, D'Alema publicly expressed frustration with NATO's strategy in Afghanistan, calling for more emphasis on political, economic, and financial aspects ,and less weight on the military side of the equation. ${ }^{125}$ D'Alema also called for a peace conference and achieved conferences on Women and the rule of law in Afghanistan. In his February 21 Senate speech, D'Alema argued that Italy would only be effective at lobbying for a peace conference if it remained a part of ISAF. $^{126}$

\section{Conclusion}

These three cases show that radical left parties that could have threatened government survival chose not to do so, despite fundamental disagreements with the government on military operations. The parties chose not to threaten survival to avoid losing an election due to voter blame and/or a coalition reshuffle. The evidence also suggests that radical parties cared about military operations less than domestic issues and less than the dominant center-left parties. In fact, the cases demonstrate the interaction of salience and blame. Because radical parties did not value foreign policy as highly as other issues they were not willing to incur voters' ire by ending the government (which they knew they would have to do given that the dominant center left valued the issue more than they did). Finally, the evidence shows that given that radical parties were not going to threaten survival they appealed to their voters through theatrical politics and by affecting how military operations were implemented.

Our paper's findings have some significant ramifications for policy and the literature. First, the inclusion of critical radical parties in future Italian governments does not necessarily mean that coalition governments will be hijacked. Second, our article's detailed case studies suggest two responses to the aforementioned mixed findings on salience. Our case studies stress that radical parties' internal

\footnotetext{
119“112a Seduta,' 25.

${ }^{120}$ Ettore Greco, "La politica estera del governo Prodi," in IAI yearbook 2007, 48.

${ }^{121}$ Nese, Marco. June 23, 2006. “Afghanistan, 1' Italia a Karzai.” Il Corriere della Sera.

${ }^{122}$ Nese, Marco. January 18, 2007. "Parisi 'blinda' l' Afghanistan: non cambia nulla.' Il Corriere della Sera.

123“Afghanistan: Berlusconi attacca il Governo." March 25, 2007. Il Sole 24 Ore.

${ }^{124}$ Ignazi, Giacomello, and Coticchia (2012, 137).

${ }^{125}$ Caprara, Maurizio. November 10, 2006. "D'Alema: 'Afghanistan, intervento da ripensare'." Il Corriere della Sera.

126“112a Seduta,” pp. 14-56.
} 
rank order of issues and their intensity of preference relative to center-left parties are both important. Most existing studies have looked at one or the other. Moreover, our article provides a focus on the interaction between salience and blame: Fear of blame is an important mechanism, but it matters because of low salience. It would be useful for further qualitative research to explore the interaction effects of blame and salience. Third, our article points out two ways that radical parties can address their voters' concerns while supporting a government that engages in military operations. Although these parties do not achieve the extreme outcomes they would prefer, they have a significant impact on policy. Our findings support those who have argued that radical parties can affect implementation. Our cases also propose, however, that radical parties engage in emotive appeals through symbolic politics. These appeals are important because they can undermine popular support for military operation.

\section{References}

Beasley, Ryan. and Juliet KaArbo. 2014. "Explaining Extremity in the Foreign Policies of Parliamentary Democracies." International Studies Quarterly 58: 729-40.

Blim Michael. 2000. "What Is Still Left for the Left in Italy? Piecing Together a Post-communist Position on Labor and Employment." Journal of Modern Italian Studies 5: 169-85.

Brighi, Elisabetta. 2013. Foreign Policy, Domestic Politics and International Relations. New York: Routledge.

Bull, Martin, and Gianfranco Pasquino. 2007. "A Long Quest in Vain: Institutional Reforms in Italy." West European Politics 30: 670-91.

Calossi, Enrico, and Fabio Sozzi. 2012. "Alla sinistra dei Socialisti. Attori politici in cerca di definizione.” Paper presented at the XXVI Annual Sisp Conference, Rome.

Clare, JoE. 2010. "Ideological Fractionalization and the International Conflict Behavior of Parliamentary Democracies.” International Studies Quarterly 54: 965-87.

Conti, Nicolò. 2008. "The Italian Parties and Their Programmatic Platforms: How Alternative?" Modern Italy 13: 451-64.

Cotta, Maurizio, And P. Isernia, eds. 1996. Il gigante dai piedi di argilla. La crisi del regime partitocratico in Italia. Bologna: Il Mulino.

Cotta, Maurizio, and Luca Verzichelli. 2000. "Italy: From 'Constrained' Coalitions to Alternating Governments." In Coalition governments in Western Europe, edited by Wolfang G. Müller and Kare Strom, 433-97. Oxford: Oxford University Press.

D’Alema, Massimo, and Federico Rampini. 1999. Kosovo, gli italiani e la guerra. Milano: Mondadori.

Davidson, Jason W. 2011. America's Allies and War. Kosovo, Afghanistan, and Iraq. Houndmills: Palgrave.

De Sio, Lorenzo. 2007. "For a Few Votes More: The Italian General Elections of April 2006." South European Society and Politics 12: 95-109.

Duhamel, Olivier. 1997. "Derrière le brouillard, le bipartisme?” Etat De L'opinion 81-97.

George, Alexander L, and Andrew Bennett. 2005. Case Studies and Theory Development in the Social Sciences. Cambridge, MA: MIT Press.

Giacomello, Giampiero and Bertjan Verbeek, eds. 2011. Italy's Foreign Policy in the 21st Century. The New Assertiveness of an Aspiring Middle Power? Lanham: Lexington Books.

Ieraci, Giuseppe. 1996. "Perché cadono i governi? La stabilità di governo nelle democrazie dell'Europa occidentale (1945-1995).” Quaderni Di Scienza Politica 3: 43-82.

Ignazi, Piero, Giampiero Giacomello, and Fabrizio Coticchia. 2012. Italian Military Operations Abroad. Houndmills: Palgrave.

KaARbo, Juliet. 1996. "Power and Influence in Foreign Policy Decision Making: The Role of Junior Coalition Partners in German and Israeli Foreign Policy." International Studies Quarterly 40: 501-30.

—. 2008. "Coalition Cabinet Decision Making: Institutional and Psychological Factors." International Studies Review 10: 57-86.

—. 2012. Coalition Politics and Cabinet Decision Making. Ann Arbor, MI: University of Michigan Press.

Kaarbo Juliet, and Ryan Beasley. 2008. "Taking it to the Extreme: The Effect of Coalition Cabinets on Foreign Policy.” Foreign Policy Analysis 4: 67-81. 
Kaufman, Stuart J. 2006. "Symbolic Politics or Rational Choice? Testing Theories of Extreme Ethnic Violence." International Security 30: 45-86.

Kisangani, Emizet F., and Jeffrey Pickering. 2011. "Democratic Accountability and Diversionary Force: Regime Types and the Use of Benevolent and Hostile Military Force." Journal of Conflict Resolution 55: 1021-46.

Октау, Sibel. 2014. "Constraining or Enabling? The Effects of Government Composition on International Commitments.” Journal of European Public Policy 21: 860-84.

Opperman, Kai, and Klaus Brummer. 2013. "Patterns of Junior Partner Influence on the Foreign Policy of Coalition Governments." British Journal of Politics and International Relations 16(4): 1-17.

Ozkececi-Taner, Binnur. 2005. "The Impact of Institutionalized Ideas in Coalition Foreign Policy Making: Turkey as an Example, 1991-2002.” Foreign Policy Analysis 1: 249-78.

Verbeek, Bertjan, and Andrej Zaslove . 2014. "The Impact of Populist Radical Right Parties on Foreign Policy: the Northern League as a Junior Coalition Partner in the Berlusconi Governments." European Political Science Review 1-22.

Walston, James. 2009. "Foreign Policy: The Difficult Pursuit of Influence." In Italian Politics 2007: Frustrated Aspirations for Change, edited by Mark Donovan and Paolo Onofri, 123-24. New York: Berghan Books. 